\title{
Implementation of the Internet of Things for Monitoring the Company's Electrical Power Consumption
}

\author{
Riklan Kango ${ }^{1}$, Suhaedi ${ }^{1}$, Fadli Awal Hasanuddin ${ }^{2}$ \\ riklan.kango@poltekba.ac.id \\ ${ }^{1}$ Politeknik Negeri Balikpapan, Indonesia \\ ${ }^{2}$ Universitas Hasanuddin Makassar, Indonesia
}

Received: Junuary 2, 2021

Revised: January 10, 2021

Accepted: January 17, 2021

\begin{abstract}
This research aims to design an electric panel monitoring system using the Internet of Things technology in company buildings so that consumers can monitor real-time electricity consumption. The energy consumption monitoring method that we propose uses PM2100 by implementing a real-time monitoring function of the power consumption of a 3-phase electric panel. The monitoring system implementation results show that the value is very close to measuring the digital multimeter measuring instrument. The monitoring system produces a current measurement accuracy of $97.38 \%$ with an error of $2.62 \%$, while the 3-phase voltage measurement error is $0.616 \%$. This system design helps companies obtain information faster to be considered data to improve efficiency in the Company.
\end{abstract}

Keywords: Electrical Energy, Internet of Things, Energy Monitoring, PM2100, kWh meter

Introduction

The office and corporate industries' electricity consumption consumes more electric power (Prayitno, 2019) than the home sector (Paryogi \& Saleh, 2019). This can affect the availability of electricity to meet two industries, which are quite large in number. (Cahyo et al., 2018). There needs to be electrical energy supervision in company departments because electric energy use's efficiency and management are currently low, and the costs are too high. (Vasanthapriyan \& Randima, 2019). The company's amount of cumulative average power consumption can only be measured and controlled by looking directly at the $\mathrm{kWh}$ meter (Pangestu et al., 2019). Users do not know a load of electrical equipment used, so they cannot control their electric pulses until electricity credits run out quickly (Andriana et al., 2019) and result in over budget (Tukadi et al., 2019). Thus, a remote monitoring system is needed to provide real-time electrical power information to obtain periodic data updates that can be analyzed quickly in the context of management and saving of electrical energy in the corporate sector.

Research on electrical energy monitoring systems has been widely carried out in recent times. Research by (Mardiana et al., 2016) monitoring electricity consumption is web-based, but the value of power and energy consumption / $\mathrm{kWh}$ is only obtained from calculating the programming language. This study produces a prototype that uses electrical energy from the same source as an electrical panel measured and monitored. So that if a blackout occurs, the measuring instrument (prototype) restarts again, and for re-measurement, it is necessary to set and recalibrate it. Research by (Habibi et al., 2017) has made a monitoring tool using the PZEM 004T Module, connected to a smartphone as a real-time media user interface. The results of monitoring the study display current, voltage, power, energy accumulation, and

Copyright (C) 2021, Journal of Asian Multicultural Research for Economy and Management Study, 
data stored in a database. This study reveals that the design of electrical energy monitoring tools has an error rate and has not been able to monitor 3 phase electrical energy and data communication still use local networks without the IoT feature. Research by (Cahyo et al., 2018) has analyzed the difference in analog $\mathrm{kWh}$ value with a microcontroller, which has a difference in value $(5-10) \mathrm{kW}$. However, the use of modules depends on the electrical system supply. This study does not have a database for past monitoring data and a web service without IoT.

The related works above only show that monitoring depends on sensors or modules, and the load is limited to electrical equipment in the home sector and is not comprehensive with the $\mathrm{kWh}$ meter system. In Indonesia, research on electrical energy management covering all loads of electronic equipment connected to a certain electrical panel for the corporate sector has not been reported. Therefore, this study provides an important solution for the company's real-time electricity $\mathrm{kWh}$ management system by monitoring the IoT-based web service media interface (Shyr et al., 2018). This research aims to design a panel electric kWh meter using the Powermeter (PM2100) module, which can avoid voltage drops because it does not require other power supply circuits, and the application of the internet and websites in monitoring systems is commonly used (Nadzif et al., 2019).

\section{Method}

This research was conducted by using the experimental research method. In the context of this research, we were designing a monitoring system device for monitoring electricity consumption with PM2100 in office buildings. Data collection was done by using observation techniques. The study was conducted at PT. Thiess Contractors Indonesia BSF (Balikpapan Support Facility), which is a purposive industrial sector, with the following considerations: 1) the location is around a vital object; 2) having routine problems of employees who always check in the field regarding the electrical panels in each building; 3) having optimized officer potential. Data collection was carried out in June-August 2020.

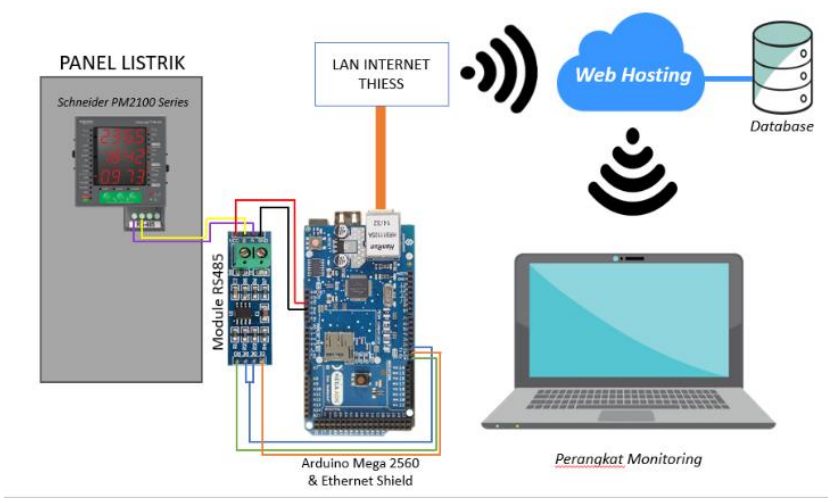

Figure 1. Schematic of the power meter monitoring system.

Figure 1 shows the procedure for our proposed electric energy consumption monitoring system. After data collection is carried out through the website monitoring system design, then data collection uses a digital multimeter measuring instrument to measure current and voltage parameters. The IoT-based monitoring system data is then tested for accuracy by comparing the actual measurement data used to determine errors with equation (1).

$$
\text { Error }=\frac{\text { monitoring value }- \text { measuring instrument value }}{\text { monitoring value }}
$$




\section{Results and Discussion}

The results of the monitoring system are displayed on the web, as in Figure 2. The system's data were obtained according to the system design for the voltage and current in the R, S, T phases of the building panel, taken on 14/06/2020. On this page, there are four parameters, namely Total kWh, Last Data Voltage, Last Data Flow, and Last Data Frequency, to display the last data sent from Arduino, which is then stored in the database. The experiment results show that the monitoring system we propose performs well under conditions of real-time access to electricity consumption.

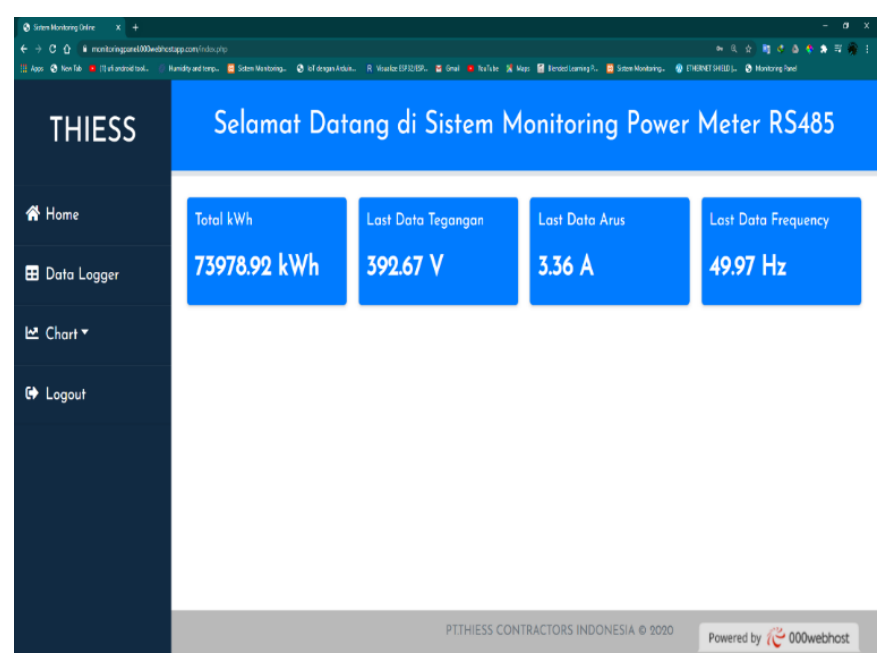

Figure 2. Display of the monitoring system homepage

Figure 3 shows a table of the readings sent from Arduino, which contains the date and time of delivery, 3 phase voltage parameters, Current, Frequency, and Total kWh. The data has been stored in the database. The print button, if you want to print the data displayed on the page or based on the date we want, is still based on what is displayed on the page.

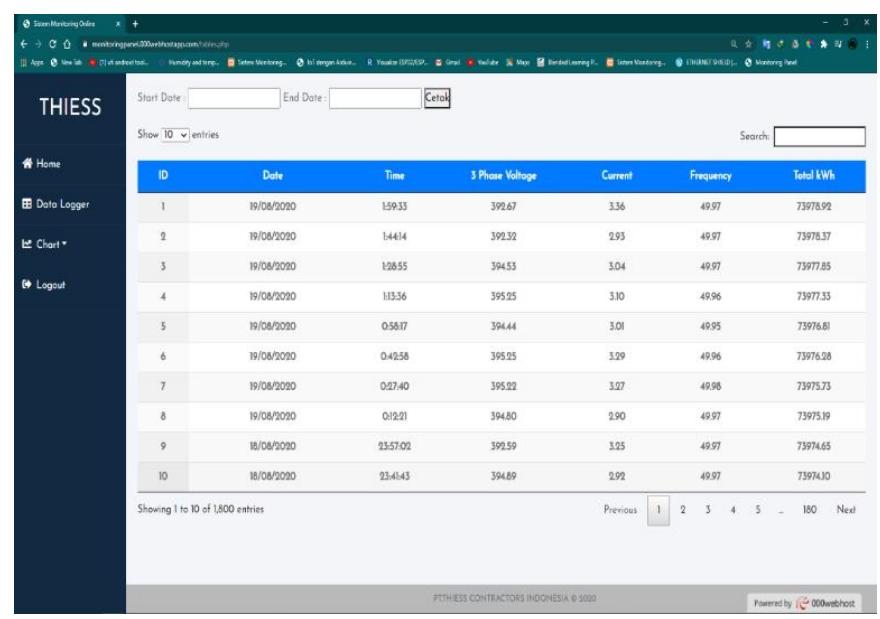

Figure 3. Display of monitoring system data logger page

This monitoring system's results need to be tested using a measuring instrument according to the measured parameters to know that this monitoring system has the right accuracy level. It can be stated that this system works well and is by calculations with measuring instruments. This measurement is carried out for two electrical parameters, namely the value of current and voltage (Voltage), to measure current and voltage value using a Digital Multimeter. Measurements were taken simultaneously, namely on 14/06/2020. 
Table I compares the monitoring system's current data to the digital multimeter's value as a whole. There is a difference in measurement between the two with their respective percentage error rates. The results of these tests, the average error percentage of $2.62 \%$, means the measurement accuracy is $97.38 \%$.

Table 1 . The results of monitoring readings of current values

\begin{tabular}{|c|c|c|c|}
\hline Time & $\begin{array}{c}\text { Value } \\
\text { monitoring }\end{array}$ & $\begin{array}{c}\text { Measuring } \\
\text { instrument value }\end{array}$ & Error \\
\hline 11.25 & 392,4 & 389,4 & 0,76 \\
\hline 11.30 & 393 & 387,3 & 1,45 \\
\hline 11.35 & 392,5 & 390,2 & 0,59 \\
\hline 11.40 & 394,5 & 390,5 & 1,01 \\
\hline 11.45 & 394,2 & 390,8 & 0,86 \\
\hline 11.50 & 394,4 & 394,2 & 0,05 \\
\hline 11.55 & 395 & 394,5 & 0,13 \\
\hline 12.05 & 395,4 & 395,1 & 0,08 \\
\hline \multicolumn{3}{|c|}{ the average error value } & 0,616 \\
\hline
\end{tabular}

Table II shows the comparison between the monitoring system voltage data to the digital multimeter's value as a whole. There is a difference in measurement between the two with their respective percentage error rates: the test results, the average percentage error of $0.616 \%$. The readings of the electrical energy parameters on the company's electricity consumption show that the monitoring system we propose can provide good reading performance in real-time access conditions via the website.

Table 2. The results of monitoring the voltage value

\begin{tabular}{|c|c|c|c|}
\hline Time & $\begin{array}{c}\text { Value } \\
\text { Monitoring }\end{array}$ & $\begin{array}{c}\text { Measuring } \\
\text { instrument value }\end{array}$ & Error \\
\hline 11.25 & 392,4 & 389,4 & 0,76 \\
\hline 11.30 & 393 & 387,3 & 1,45 \\
\hline 11.35 & 392,5 & 390,2 & 0,59 \\
\hline 11.40 & 394,5 & 390,5 & 1,01 \\
\hline 11.45 & 394,2 & 390,8 & 0,86 \\
\hline 11.50 & 394,4 & 394,2 & 0,05 \\
\hline 11.55 & 395 & 394,5 & 0,13 \\
\hline 12.05 & 395,4 & 395,1 & 0,08 \\
\hline \multicolumn{3}{|c|}{ the average error value } & 0,616 \\
\hline
\end{tabular}

Monitoring results regarding changes in the panel's current value and total $\mathrm{kWh}$, data monitoring will be carried out starting on August 17, 2020, at 19:05:45 and August 18, 2020, at 17:18:48. The author's reason for taking these two different times is at 19:05:45 to 05:18:24, at which time office activities decrease, and only a few people are only still working at that hour and 07: $05: 36$ to $17: 18: 48$, this time is the busy time of activity in the office.

Table III shows the high current value at 19:05:45 with a value of 6.35 A while the low current value at 4:17:08 time with a value of $2.83 \mathrm{~A}$. There is also an average current of 3.6 A. For the total increase in $\mathrm{kWh}$, starting from 19:05:45 to 04:17:08 with a total value of $22.63 \mathrm{kWh}$, this value is obtained from the total number of $\mathrm{kWh} 11$ th monitoring data minus the first monitoring data. 
Table 3. Monitoring Result IoT System (19: 05: 45--04: 17: 08

\begin{tabular}{|c|c|c|c|}
\hline Date & Time & Current & kWh \\
\hline $17 / 08 / 2020$ & 19:05:45 & 6,35 & 73895,49 \\
\hline $17 / 08 / 2020$ & $20: 07: 01$ & 6,22 & 73898,13 \\
\hline $17 / 08 / 2020$ & 21:08:16 & 3,08 & 73900,78 \\
\hline $17 / 08 / 2020$ & $22: 09: 32$ & 2,86 & 73903,4 \\
\hline $17 / 08 / 2020$ & $23: 10: 48$ & 2,85 & 73905,65 \\
\hline $18 / 08 / 2020$ & $00: 12: 04$ & 3,5 & 73907,68 \\
\hline $18 / 08 / 2020$ & $01: 13: 20$ & 2,97 & 73909,8 \\
\hline $18 / 08 / 2020$ & $02: 14: 36$ & 2,85 & 73911,92 \\
\hline $18 / 08 / 2020$ & $03: 15: 52$ & 3,04 & 73913,95 \\
\hline $18 / 08 / 2020$ & $04: 17: 08$ & 2,83 & 73916,04 \\
\hline & Average & 3,6 & 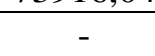 \\
\hline
\end{tabular}

Table IV shows the high current value at 15:16:01 with a value of $12.53 \mathrm{~A}$ while the low current value at 08:06:53 with a value of 3.78 A. There is also an average current of 7.14 A. For the total increase in $\mathrm{kWh}$ starting at $07: 05: 36$ to $17: 18: 48$ with a total value of 35.94 $\mathrm{kWh}$, this value is obtained from the total number of $\mathrm{kWh}$ in the 11th monitoring data minus the first monitoring data.

Table 3. Monitoring Result IoT System (19: 05: 45--04: 17: 08

\begin{tabular}{|c|c|c|c|}
\hline Date & Time & Current & kWh \\
\hline $18 / 08 / 2020$ & $07: 05: 36$ & 7,08 & 73922,06 \\
\hline $18 / 08 / 2020$ & 08:06:53 & 3,78 & 73925 \\
\hline $18 / 08 / 2020$ & 09:08:09 & 3,82 & 73928,21 \\
\hline $18 / 08 / 2020$ & 10:09:25 & 4,11 & 73931,33 \\
\hline $18 / 08 / 2020$ & 11:10:41 & 8,02 & 73934,42 \\
\hline $18 / 08 / 2020$ & $12: 11: 57$ & 7,03 & 73938,08 \\
\hline $18 / 08 / 2020$ & 13:13:13 & 7,55 & 73941,46 \\
\hline $18 / 08 / 2020$ & $14: 14: 28$ & 9,84 & 73945,54 \\
\hline $18 / 08 / 2020$ & $15: 16: 01$ & 12,53 & 73949,79 \\
\hline $18 / 08 / 2020$ & $16: 17: 17$ & 7,87 & 73954,22 \\
\hline & Average & 7,14 & - \\
\hline
\end{tabular}

The monitoring results between the time (19:05:45 - 04:17:08) and (07:05:36 - 16:17:17) show the difference in the average value of the current; this happens because at the time (19:05: 45 - 04:17:08) activities in the office are less or less frequent, while from morning to evening (07:05:36 - 16:17:17) is the active period for company employees to use electrical equipment so that the electrical loads more active. The increase in the total value of $\mathrm{kWh}$ during the time interval (19:05:45 - 04:17:08) is lower than that in the time interval $(07: 05: 36$ - 16:17:17), this is because in the morning to evening there are lots of loads - The dynamic electricity load is because of the activities of the Company's employees compared to night to morning.

Changes in the value of the current in the process of much electrical equipment used to be a load directly affect the total $\mathrm{kWh}$ value produced. This implies a drastic change in the real $\mathrm{kWh}$ trajectory graph at 07:05:36 - 16:17:17. However, the threshold value changes will not cause many errors when the monitoring system we propose is implemented. The flow value trajectory graph shows that the reading trajectory remains stable at low or high threshold values. Meanwhile, $\mathrm{kWh}$ 's total value shows the length of time to use electrical equipment is directly proportional to power consumption. Thus, the design of the PM2100 as the proposed

Copyright ( $)$ 2021, Journal of Asian Multicultural Research for Economy and Management Study, 
IoT-based electrical energy consumption monitoring system can handle the reading of different electrical energy value parameters within a reasonable range, which is very useful for information data management considerations in the context of electrical efficiency in the Company.

Explain the results of the research in the form of problem-solving analyzed using relevant theories. The results of the study also revealed the findings of the investigation. Discussion is accompanied by logical arguments by linking the results of research with approach, the results of other studies.

\section{Conclusion}

This research presents a new method for real-time monitoring of electrical energy consumption based on the Internet of Things at PT. Thiess Contractors Indonesia. The PM2100 can be used for monitoring electrical panels with good value accuracy. The results were compared with matching conventional measuring instruments, namely digital multimeters. The experiment results show that the proposed monitoring system offers robustness and flexibility in situations where there is a lot of electrical equipment used during the Company's activity period from morning to evening. Further research can be carried out by increasing the monitoring system's accuracy and implementing a reading system for other electricity consumption parameters.

\section{Acknowledgments}

The authors would like to thank PT. Thiess Contractor Indonesia, for their financial support of the research application. The author also thanks to the Balikpapan State Polytechnic for financial support through the (Penelitian Kompotitif) program, the driving force for this research, and colleagues for its useful discussions.

\section{References}

Andriana, -, Zuklarnain, -, \& Baehaqi, H. (2019). Sistem kWH Meter Digital Menggunakan $\begin{array}{lllll}\text { Modul PZEM-004T. Jurnal TIARSIE, } & \end{array}$ https://doi.org/10.32816/tiarsie.v16i1.43

Cahyo, M. D., Ubaidillah, A., \& Ibadillah, A. F. (2018). Rancang Bangun Sistem Proteksi dan Monitoring Energi Listrik Berbasis Mikrokontroler Menggunakan Visual Studio Uji Coba Diakses di PT. PANCAWANA INDONESIA. 1, 1-6.

Habibi, F., Setiawidayat, S., \& Mukhsim, M. (2017). Alat Monitoring Pemakaian Energi Listrik Berbasis Android Menggunakan Modul PZEM-004T. Prosiding Seminar Nasional Teknologi Elektro Terapan 2017, 01(01), 157-162.

Mardiana, Despa, D., Gusmedi, H., Nama, G. F., Teknik, J., Unila, E., Teknik, J., Unila, E., Teknik, J., Unila, E., Teknik, J., \& Unila, E. (2016). Aplikasi Monitoring Sistem Kelistrikan Jte Unila Berbasis Bcm2835. Seminar Nasional APTIKOM, 4(1), 28-29.

Nadzif, H., Andrasto, T., \& Aprilian, S. (2019). Sistem Monitoring Kelembaban Tanah dan Kendali Pompa Air Menggunakan Arduino dan Internet. Jurnal Teknik Elektro, 11(1), 26-30. https://doi.org/10.15294/jte.v11i1.21383

Pangestu, A. D., Ardianto, F., Alfaresi, B., Elektro, J. T., Teknik, F., Muhammadiyah, U., Elektro, P. S., Teknik, F., \& Palembang, U. M. (2019). Sistem Monitoring Beban Listrik Berbasis Arduino Nodemcu Esp8266. Jurnal Ampere, 4(1), 187-197.

Paryogi, D. B., \& Saleh, A. (2019). Design Of Real-Time Electrical Power Consumption 
Monitoring System In Office Buildings Using SCADA Based RS485. 3(10), 46-50.

Prayitno, B. (2019). Prototipe Sistem Monitoring Penggunaan Daya Listrik Peralatan Elektronik Rumah Tangga Berbasis Internet of Things. Petir, 12(1), 72-80. https://doi.org/10.33322/petir.v12i1.333

Shyr, W.-J., Zeng, L.-W., Lin, C.-K., Lin, C.-M., \& Hsieh, W.-Y. (2018). Application of an Energy Management System via the Internet of Things on a University Campus. Eurasia Journal of Mathematics, Science and Technology Education, 14(5), 17591766. https://doi.org/10.12973/ejmste/80790

Tukadi, Widodo, W., Ruswiensari, M., \& Qomar, A. (2019). Monitoring Pemakaian Daya Listrik Secara Realtime Berbasis Internet of Things. 581-586.

Vasanthapriyan, S., \& Randima, V. (2019). Design IoT based smart electricity power saving university: Analysis from a lecture hall. Journal of Computer Science, 15(8), 10971107. https://doi.org/10.3844/jcssp.2019.1097.1107 